\title{
Smart Key Implementation for BTS Gate Door Based on Internet of Things
}

\author{
Rahmad Hidayat ${ }^{1}$, Syafruddin ${ }^{2}$, Sudarmanto $^{3}$, Sabar Santoso $^{4}$, Ganjar Kurniawan Sukandi ${ }^{5}$, \\ Handayani Saptaji Winahyu ${ }^{6}$ \\ \{rhidayat4000@gmail.com¹, syafruddin59@gmail.com², sudarmanto.mt@gmail.com³ \\ STT Mandala, Soekarno Hatta 597, Bandung ${ }^{12456}$, PT Astindo Dot Net, Mangga Dua, Jakarta ${ }^{3}$
}

\begin{abstract}
At present, access to Base Transceiver System (BTS) takes place for a long time, among others due to permits still being carried out manually. In this study, an experimental study of the making of smart keys was conducted to offer solutions to the above problems. This internet of things (IoT) research is carried out through the detection of the existence of standard keys; look for correlation of tower distance with the opening process of the tower fence; experimental design and smart key implementation with the Android application and ESP8266 microcontroller. The result, allows the BTS location permit process to take place on the site and immediately known to the Network Operation Center via Android. Thus, the process of access to the site becomes faster, and the BTS main work is also completed faster; monitoring all activities on the site is better, and there is evidence of complete site activities.
\end{abstract}

Keywords: IoT, smart key, android, ESP8266, NOC, BTS.

\section{Introduction}

BTS Tower (Base Transceiver Station) is the operator's transmission tower that has many devices in it. In one tower environment, there is at least one RBS (Radio Base Station) device, a rectifier for power supply, and a $\mathrm{kWh}$ meter box. For RBS and rectifier devices that are the indoor type, usually placed in a shelter equipped with an air conditioner (AC) to keep the room temperature cool. And in some towers with high utilization rates, a generator is also set up to maintain electricity availability so that BTS can still operate. Because of the large number of devices that are in the tower environment, causing a lot of maintenance activities to keep the BTS device operating. In addition to maintenance activities, there are also 'project' activities to add devices or change device configurations. Thus the frequency of key lending to access into the tower environment becomes very high. This eventually caused the tower fence's key to becoming unclear (even lost), causing an officer to be difficult to enter the location. The second problem is the location of the lock fence lending to the operator's office which is usually far from the tower location, which causes officers to travel long distances to return to the tower location and the process takes longer. The contribution of this research is the production of the electronic smart padlock prototypes that can help accelerate maintenance and handling of disruption activities and accelerate the expansion of telecommunications networks.

ICCSET 2018, October 25-26, Kudus, Indonesia

Copyright $(9) 2018$ EAI

DOI 10.4108/eai.24-10-2018.2280529 


\section{Literature review}

In line with the development of cellular communication due to the increasing need for various digital applications today, communication technology is currently evolving towards the fifth generation $(5 \mathrm{G})$ which implements smart antenna and millimeter wave propagation. [1] In anticipation of the coming of the technology, every telecommunication operator will expand its network equipment, including in BTS, both in new locations and existing locations. For this reason, more and more technicians will come to the BTS for the maintenance and expansion activities mentioned above, and there will be more accessible through the gate. In research [2], the author discusses making turnstile control devices by utilizing Bluetooth technology on mobile phones that are connected to a Bluetooth module on Arduino, as input to open and close the gate automatically. This tool is a series of small shaped components of a door that can shift automatically controlled using an Arduino microcontroller program. The research result that Android-based smartphone can control the gate through an interface on the smartphone screen. Then the development of communication technology runs mutually reinforcing with the technological advances of the internet of things. [3]

\subsection{Android operating system}

Android is a Linux-based operating system for cellular phones such as smartphones and tablet computers. Android provides an open platform for developers to create their applications for use by various mobile devices. Initially, Google Inc. bought Android Inc., newcomers who made software for cell phones. Then to develop Android, the Open Handset Alliance was formed, a consortium of 34 hardware, software and telecommunications companies, including Google, HTC, Intel, Motorola, Qualcomm, T-Mobile, and NVidia. [4]

\subsection{ESP 8266}

ESP8266 is a WIFI module that has a UART serial port to communicate with other controllers. The ESP8266 module has a relatively small and the price is relatively high.ESP8266 is a low cost but reliable serial to WIFI module. This module has many types ranging from ESP-01 variety, ESP-02, ESP-03, and so on to the latest variant, ESP-14. Besides the 'official' type above there are also products from other manufacturers but use IC 8266 chips. One of them is ESP 201. This type has a white color and has an RSMA connector to connect to an external antenna. So the ESP 201 board type is indeed superior, it can be combined with an external antenna so that the WIFI beam can be further away. [5]

\subsection{Servomotor}

Servo motors are one type of DC motor. Servo is a perfect control motor that can be ordered to rotate in certain positions. There are two types of servo motors, the Continuous servo motor type, and the Standard servo motor. Both of these servo motors are not much different just in the rotation. The following is an explanation of both types of servo motors:

a) Standard Servo Motor. This type of servo motor is only able to move both ways (CW and $\mathrm{CCW}$ ) with a deflection of each angle reaching $90^{\circ}$ so that the total deflection angle from right-center-left is $180^{\circ}$. 
b) Continuous Servo Motor. This type of servo motor can move in both directions (CW and $\mathrm{CCW}$ ) without limiting the rotational angle of the deflection (can rotate continuously). [6], [7].

\subsection{Server-side scripting PHP}

Rasmus Lerdorf first created PHP in 1994. Server Side Scripting is a technology in web programming (scripting) where the script (program) was translated on the server. By using server-side scripting, it is possible to generate dynamic web pages. PHP is one example of server-side scripting. Things that can be done using PHP include: reduces time to make largescale web; able to create the interactive network; supports e-commerce (shopping charts). PHP also has several advantages, including free, PHP can be obtained free of charge and free to use; multi-platform, can be run in various operating systems such as Unix, Linux (Red Hat, Ubuntu, Mandriva, Fedora, etc.), Microsoft Windows, Mac OS, etc.; supports many databases, such as MS-SQL, MySQL, Oracle, PostgreSQL, etc.; on the fly, PHP can be used to create text documents, Word, Excel, PDF, create images and flash, also create files like zipping, XML, and others. [8], [9]

\subsection{MySQL database}

MySQL is a SQL database management system software (English: database management system) or DBMS that is multithreaded, multi-user, with around 6 million installations worldwide. MySQL AB makes MySQL available as free software under the GNU General Public License (GPL) license, but they also sell under commercial permits for cases where the use is not compatible with GPL usage. Unlike Apache, which is a software developed by the general community, and their respective authors own the copyright for the source code, MySQL is owned and sponsored by a Swedish commercial company, MySQL AB. MySQL $\mathrm{AB}$ holds full copyright almost all the source code. The two Swedes and one Finnish who founded MySQL AB are David Axmark, Allan Larsson, and Michael "Monty" MySQL (My Structured Query Language) is one database of many other databases such as Oracle, MS SQL, PostgreSQL and many more. All have almost the same functions and benefits, but the work is a little different. [8], [9]

\section{Method}

In designing and implementing a smart key system for the BTS gate, we used experimental research methodology with the following stages:

\subsection{Description of the problem}

The steps for Description of the problem are: make an overview of the phenomenon of lending the tower fence lock; designing ways to approach problem-often solving the loss of fence locks; collect activity data in and out of the tower; reporting. 


\subsection{Case study in the field}

The steps for the case study are: study the pattern of borrowing the tower fence lock; collecting data on officer activities in and out of the tower; organize key borrowing data and information, then reconstruct it if it is done with a critical smart application; reporting.

\subsection{Correlational study}

The steps of correlational study are: manually collecting key lending data; look for correlations of the duration of the fence lock opening process; look for variables causing the length of the critical lending process with tower officer activity data; analyze collected data; reporting.

\subsection{Comparative causal studies}

The steps of comparative causal studies are: defining problems; the difference in the use of smart keys with manual fence locks; investigate the causal relationship between the use of quick keys and the efficiency of crucial lending time; analyze data; reporting.

\subsection{System design}

The steps for system design are: choosing the right application to control the smart key; choose the controller that controls the smart key. After that choose the communication line using WIFI to contact the smart key of the smartphone; choose a web server using Apache, PHP5, javascript, bootstrap as a framework and MySQL as database engine; designing systems and implementing tools; conduct experiments; do testing tools, and reporting. [8][12] 


\subsection{Topology and how the system works}

The topology of the smart key system for the BTS gate is as follows:

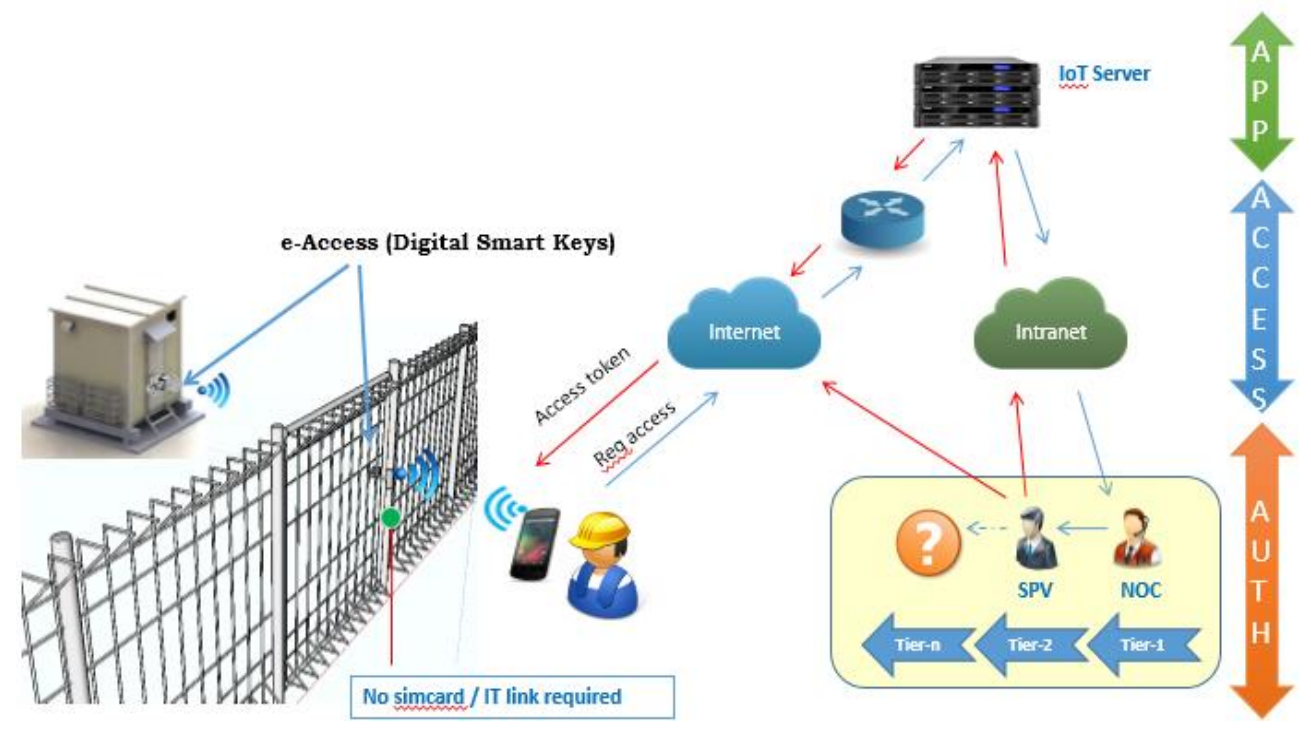

Fig.1. The topology of the key intelligent network.

An engineer who will enter the site/BTS must apply for a permit like the usual procedure. Next, the vendor will get the permission as needed to the BTS. This permit can be in the form of Work Order (WO), or Trouble Ticket (TT). WO is a permit given to the engineer for work that is maintenance/equipment in the BTS. Whereas TT is a permit granted to engineers for work that is repairing tools or networks. The No WO/TT will be loaded into the Android application that will be submitted when it will open a smart lock/electronic lock on the BTS gate.

When the engineer is in front of the BTS gate, he then asks for permission by opening the application that has been provided (first installed on each smartphone). When the request has been made and arrived at the server, the NOC will get a notification that someone will open the gate on a particular site/BTS. The NOC then checked the validity of the engineer who requested permission to open the entrance through the application. NOC can check the validity of access requests via WO/TT and photos sent through the app (the picture of engineers are in the database on the server). When all data is valid, the NOC will give the engineer permission in the form of a token. This token will be 'sent' to the engineer through an Android application on the smartphone of an engineer. If the token has been received at the engineer's side, there will be a notification indicating that the engineer has obtained permission to open the smart key/electronic padlock installed at the site/BTS gate. When the engineer gets a license (token) from the NOC, the virtual button in the Android application on the smartphone of the engineer will be active, so that the engineer can press it. When the 'OPEN' button is pressed, the smart key will open so that the engineer can enter the site/BTS. 


\subsection{Research object and location}

This research was conducted at several sites (BTS) in different locations. These sites are XL operator-owned assets located in Bandung, West Java. Data collection is carried out during working hours, i.e., 08.00 to 17.00 WIB. While the object of the research was carried out by the engineer of PT Infratech Indonesia as BTS maintenance provider for CME (Civil, Mechanic, and Environment), PT PMT as a network maintenance provider for BTS and PT Bharathi as the BTS installation provider. The research was carried out randomly by not paying attention to the work of each provider, but it still noted the work carried out in question and recorded the time of the engineer coming (opening the gate), completing the job until the work was completed which was marked by closing the gate. Data collection method is done by recording the time based on the data on the cell phone during the field study (visiting the BTS), then interviewing the engineer who came to the BTS.

\section{Results and Discussion}

\subsection{Data collection process}

The research was carried out for one month with the first two weeks carried out to record the site's access time manually without using an electronic padlock application. Site access time is then recorded manually starting from the work assigned to a particular engineer. After that, the time when the engineer comes to the site, the time needed when the engineer borrows the key, the time when the engineer unlocks the gate, the time is taken when the engineer does the job and who the last time the engineer finished doing the job and closed the gate. Two weeks later the research was carried out by adding a smart key that had been designed to the BTS gate. This intelligent key was installed after obtaining permission from the BTS guards and PT PMT as the party responsible for access of BTS owned by PT XL Axiata. The time recorded begins with the arrival of the engineer who will do the work at the BTS, then the engineer runs the application that has been made to unlock the smart key, and finally when the engineer closes the original key after completing work. This time recording is done automatically recorded on the server based on the application we have made. For data obtained from the form is the name of the engineer; company name engineer; access time; access requirements; and photo engineer for authorization and proof of arrival to the site.

All the data above must be filled by the engineer who will access the site (must be done right in front of the smart key), then the engineer must send it to the server using the internet through their respective smartphones. After the data has arrived on the server, then the engineer waits for authorization from the NOC whether it is permitted or not to open the lock and do work on the BTS. If permitted, the engineer will get a notification that he is permitted and the engineer can open an electronic padlock so he can enter the site and do his work. To open and close the smart key can be done through the Android application that we have created. Manual recording data and data that is on the server are then withdrawn (downloaded) to be later used as analytical material to determine the effectiveness of electronic padlock installation for access management at the site/BTS gate. Data obtained from the application is then compared with data collected during manual recording before the smart key is installed. 


\subsection{Data record on the server}

Figure 1 and 2 show manual data recording before and after a smart key is installed:

\begin{tabular}{|c|c|c|c|c|c|c|c|}
\hline Tgl & $\begin{array}{l}\text { Req } \\
\text { ijin }\end{array}$ & $\begin{array}{l}\text { Buka } \\
\text { gerbang }\end{array}$ & $\begin{array}{l}\text { Tutup } \\
\text { gerbang }\end{array}$ & Nama & Vendor & Site & Keperluan \\
\hline 6-1-17 & 08.00 & 13.00 & 14.00 & Aprizal & PT. HS & $\begin{array}{l}\text { 2220- } \\
\text { Arcamanik }\end{array}$ & $\begin{array}{l}\text { Perawatan } \\
\text { BTS }\end{array}$ \\
\hline $7-1-17$ & 09.00 & 14.30 & 16.00 & Andri & PT. HS & HUT Kircon & $\begin{array}{l}\text { Perbaikan } \\
\text { tranmisi }\end{array}$ \\
\hline $7-1-17$ & 10.00 & 13.30 & 14.00 & Deni & PT. PMT & $\begin{array}{l}\text { 2231- } \\
\text { Leuwigajah }\end{array}$ & $\begin{array}{l}\text { Perawatan } \\
\text { BTS }\end{array}$ \\
\hline $8-1-17$ & 08.00 & 14.00 & 17.00 & Budi & $\begin{array}{l}\text { PT. } \\
\text { Infratech }\end{array}$ & $\begin{array}{l}\text { 2241- } \\
\text { Cimahi }\end{array}$ & $\begin{array}{l}\text { Perawatan } \\
\text { genset }\end{array}$ \\
\hline 8-1-17 & 09.00 & 14.00 & 15.00 & Deni & PT PMT & $\begin{array}{l}\text { 2241- } \\
\text { Cimahi }\end{array}$ & $\begin{array}{l}\text { Perawatan } \\
\text { BTS }\end{array}$ \\
\hline $9-1-17$ & 08.00 & 13.00 & 14.00 & Aprizal & PT. HS & $\begin{array}{l}\text { 2212- } \\
\text { Cisaranten }\end{array}$ & $\begin{array}{l}\text { Upgrade } \\
\text { RBS }\end{array}$ \\
\hline $9-1-17$ & 08.00 & 15.30 & 17.00 & Aprizal & PT. HS & $\begin{array}{l}\text { 2214-Riung } \\
\text { Bdg }\end{array}$ & $\begin{array}{l}\text { Upgrade } \\
\text { RBS }\end{array}$ \\
\hline
\end{tabular}

Fig. 2. Manual data recording before an intelligent key is connected.

\begin{tabular}{|c|c|c|c|c|c|c|c|}
\hline TgI & $\begin{array}{l}\text { Req } \\
\text { ijin }\end{array}$ & $\begin{array}{l}\text { Buka } \\
\text { gerbang }\end{array}$ & $\begin{array}{l}\text { Tutup } \\
\text { gerbang }\end{array}$ & Nama & Vendor & Site & Keperluan \\
\hline $13-1-17$ & 10.00 & 10.15 & 11.30 & Aprizal & PT. HS & $\begin{array}{l}2220- \\
\text { Arcamanik }\end{array}$ & $\begin{array}{l}\text { Perawatan } \\
\text { BTS }\end{array}$ \\
\hline 14-1-17 & 11.00 & 11.10 & 12.00 & Andri & PT. HS & HUT Kircon & $\begin{array}{l}\text { Cek } \\
\text { tranmisi }\end{array}$ \\
\hline $14-1-17$ & 13.00 & 13.20 & 14.00 & Deni & PT. PMT & $\begin{array}{l}\text { 2231- } \\
\text { Leuwigajah }\end{array}$ & $\begin{array}{l}\text { Perawatan } \\
\text { BTS }\end{array}$ \\
\hline $15-1-17$ & 09.30 & 09.40 & 10.30 & Budi & $\begin{array}{l}\text { PT. } \\
\text { Infratec } \\
\text { h }\end{array}$ & $\begin{array}{l}\text { 2241- } \\
\text { Cimahi }\end{array}$ & $\begin{array}{l}\text { Perawatan } \\
\text { genset }\end{array}$ \\
\hline $15-1-17$ & 11.00 & 11.10 & 12.00 & Deni & PT PMT & $\begin{array}{l}\text { 2241- } \\
\text { Cimahi }\end{array}$ & $\begin{array}{l}\text { Perawatan } \\
\text { BTS }\end{array}$ \\
\hline 16-1-17 & 08.00 & 08.15 & 09.00 & Aprizal & PT. HS & $\begin{array}{l}\text { 2212- } \\
\text { Cisaranten }\end{array}$ & $\begin{array}{l}\text { Cek } \\
\text { konfigurasi } \\
\text { RBS }\end{array}$ \\
\hline $16-1-17$ & 10.00 & 10.10 & 11.00 & Aprizal & PT. HS & $\begin{array}{l}\text { 2214-Riung } \\
\text { Bdg }\end{array}$ & $\begin{array}{l}\text { Cek } \\
\text { konfigurasi } \\
\text { RBS }\end{array}$ \\
\hline
\end{tabular}

Fig. 3. Data record on the server after the smart key is installed. 


\subsection{Design of automatic smart key and its application}

This smart electronic key is intended to facilitate access management of a site/BTS owned by the operator. From the original one who has to borrow the keys manually, it is a condition where the engineer can directly enter the site after first asking permission through this application. If permission is granted by the NOC (Network Operation Center), the engineer can open a smart key (electronic padlock) and can enter the site.

This smart electronic key for BTS gates consists of three applications, namely: electronic padlock, installed at the entrance of the site/BTS; client application, in the form of an Android app installed on each smartphone's vendor; server application, an application that is in NOC. For this research, our server application is hosting in cloud computing. For company needs can be developed so that this server application can be placed on the company's internal server.

\subsection{Smart key application on android smartphones}

For the smart key to work, the engineer must enter the $5 \mathrm{~V}$ voltage from the power bank to the smart key via the USB port available at the bottom of the smart key. A moment later the smart key will live which is marked by the active, crucial intelligent SSID with the name 'eAccess.' This SSID is encrypted with WPA2 technology so that not all WIFI clients can connect to it. To link to this SSID, the smartphone engineer must know the SSID password. The password is in the token that the NOC will later give when the engineer finishes asking for permission through the application.

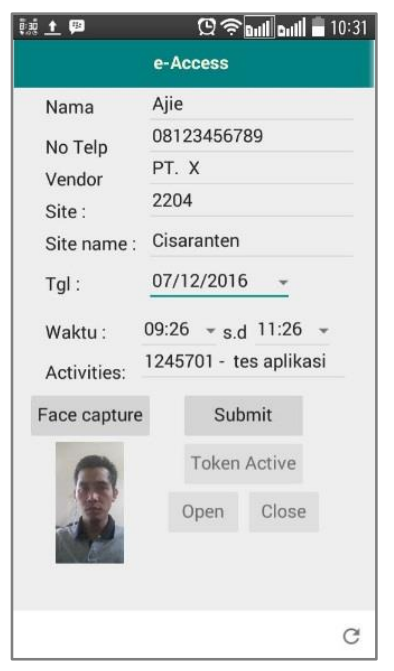

Fig.4. The display on an Android smartphone. 


\subsection{Smart key server application experimental results}

To open a server application can be done through the web browser. The next moment the display will appear for the username and password login as follows:

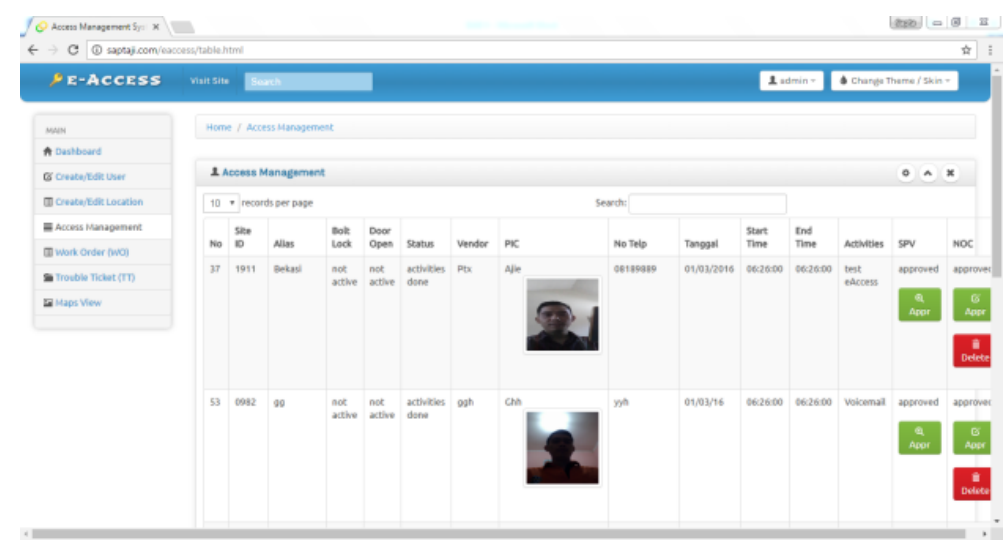

Fig.5. The server display.

Thus the NOC can check whether an engineer comes from an official provider and has obtained permission from PT XL Axiata. If all data has been tested and validated, the NOC can press the 'Approved' button in the 'NOC' column. If this button is pressed, the electronic access token will be given to the engineer who submitted the entry permit.

\section{Conclusion}

This Android-based smart key application and the ESP8266 microcontroller can make it easier for telecommunications companies to regulate access to sites/BTS. With the application of smart key for BTS turnstiles, engineers or field technicians can enter the site/BTS faster than key lending manually; The NOC can help control who and when it is time for someone to enter the site/BTS. If using an ordinary key, this cannot be done. Then also with the smart key application for the BTS turnstile, there is historical data of anyone who enters the site/BTS, so that when there is theft/destruction of the company's assets in the tower, it can be faster and more precise in its search.

\section{References}

[1] R. Hidayat, Rushendra, and E. Agustina, "Digital beamforming of smart antenna in millimeterwave communication," in 2017 International Conference on Broadband Communication, Wireless Sensors and Powering (BCWSP), 2017, pp. 1-5.

[2] A. Syofian, "PENGENDALIAN PINTU PAGAR GESER MENGGUNAKAN APLIKASI SMARTPHONE ANDROID DAN MIKROKONTROLER ARDUINO MELALUI BLUETOOTH," J. Tek. Elektro - Inst. Teknol. Padang, vol. 5, no. 1, 2016. 
[3] T. Listyorini and R. Rahim, "A prototype fire detection implemented using the Internet of Things and fuzzy logic,” World Trans. Eng. Technol. Educ., vol. 16, no. 1, pp. 42-46, 2018.

[4] D. Griffiths, Head first android development. Sebastopol, USA: O'Reilly Media, Inc., 2015.

[5] A. Allan, Learning ESP8266: build the internet of things with the arduino ide and raspberry pi. Sebastopol, USA: O'Reilly Media, Inc., 2016.

[6] G. E. Gibson, Starting smart: key practices for developing scopes of work for the facility. Washington DC: The National Academies Press, 2003.

[7] E. Gertz, Environmental monitoring with arduino. Sebastopol, USA: O'Reilly Media, Inc., 2012

[8] R. Nixon, Learning php, mysql, and javascript. Sebastopol, USA: O’Reilly Media, Inc., 2009.

[9] J. Spurlock, Bootstrap. Sebastopol, USA: O’Reilly Media, Inc., 2013.

[10] Wikipedia, “Apache http server," 2012. [Online]. Available: https://id.wikipedia.org/wiki /Apache_HTTP_Server.

[11] P. Waher, Learning internet of things. Birmingham, UK: Packt Publishing, 2015.
[12] Wikipedia,
"Internet
of things,"
2015.
[Online].
Available: https://en.wikipedia.org/wiki/Internet_of_Things. 